\title{
Angielskie, francuskie i polskie tradycje biografistyki. Wprowadzenie do tematu
}

Anna Nasiłowska

TEKSTY DRUGIE 2019, NR 1, S. 41-60

DOI: 10.18318/td.2019.1.4 | ORCID: 0000-0002-6171-5662

\section{Różnice podejścia}

Wydawałoby się, że autor biografii powinien cenić gatunek, który uprawia, zwłaszcza że napisanie dobrze udokumentowanej opowieści o życiu pisarza wymaga bardzo solidnych poszukiwań źródłowych, co zabiera kilka lub kilkanaście lat. Któż chciałby poświęcić długie lata ciężkiej pracy zajęciu, którego efektów nie będzie cenić? A jednak przekonania o służebności i drugorzędności biografii są w Polsce niezwykle silne. Zdzisław Najder, autor Życia Conrada, może na wszelki wypadek, ze względu na dominujące w polskim środowisku humanistycznym opinie, we wstępie do swojej książki z 1980 roku podkreślał swój sceptycyzm wobec biografizmu:

Na ogół biografia dla badaczy literatury, krytyków a także (i zwłaszcza!) dla „zwykłych czytelników - a „specjaliści” nie powinni się od nich

Anna Nasiłowska prof. dr hab., historyczka literatury, pisarka, poetka. Jest autorką biografii: Jean-Paul Sartre i Simone de Beauvoir (WL 2006), Maria Pawlikowska-Jasnorzewska czyli Lilka Kossak (2010) i Wolny agent Umeda i druga Japonia (2013). Ostatnio opublikowała zbiór wierszy Ciemne przejścia (2018), w przygotowaniu wydawniczym tom Historia literatury polskiej. Kontakt: anna. nas@wp.pl 
zanadto różnić - to tylko materiał pomocniczy, ułatwiający formułowanie stwierdzeń i hipotez dotyczących wpływów, przynależności do prądów i grup, uczestnictwa w życiu intelektualnym i artystycznym epoki, a także przetwarzania osobistych doświadczeń w tekst literacki. W przypadkach pisarzy „nietypowych”, to jest takich, którzy odchylają się od zasadniczych wzorów konwencji artystycznych i myślowych swojego czasu, biograf pełni rolę jakby leksykografa ustalającego sens używanych przez danego autora znaków - przez wskazywanie nie tyle na jego intencje, co na zasoby kulturowe. ${ }^{1}$

Poza tym - może także uprzedzając ewentualne negatywne reakcje przyznawał się do braku talentu biografa. Tymczasem książka przynosi obraz wczesnych lat Conrada i tych elementów jego życia, których nie mogą łatwo wyjaśnić czytelnicy i autorzy brytyjscy, i amerykańscy, nie mając ani wystarczającej orientacji w realiach historycznych, ani dostępu do polskich źródeł. Biografia Najdera, przełożona na angielski przez jego żonę, ukazała się zresztą dwukrotnie².

Biografia angielskiego pisarza polskiego pochodzenia uczestniczy w dwu, odmiennych tradycjach krytycznych. Piszący o styku kultur mają świadomość, że ukształtowane w kręgu polskiej humanistyki oceny, w wypadku autorów zakorzenionych w odmiennej tradycji, muszą zostać zrelatywizowane.

Ewa Wiegant artykuł Biografizm w twórczości naukowej i krytycznej Tymona Terleckiego zaczyna od znamiennych uwag:

Zdawałoby się, że położone w tytule słowo „biografizm” jako związane z genetyczno-pozytywistycznymi metodami nauki o literaturze, jest nieporozumieniem. Nastąpiło przecież, przypieczętowane przez strukturalizm, rozdzielenie biografistyki i historii literatury. Przypisywać komuś biografizm, to zatem skazywać go na metodologiczną staroświeckość. Niemniej, nawet w okresie triumfującego strukturalizmu, zdarzały się próby podważenia tego naukowego stereotypu. ${ }^{3}$

1 Z. Najder Życie Conrada-Korzeniowskiego, PIW, Warszawa 1980, s. 5-6.

2 Z. Najder Joseph Conrad: a Life, Columbia S.C. Camden House, 2007, 2011. Poza tym; J. Conrad A Chronicle, N.J., Rutgers University Press, New Brunswick 1983, Conrads's Polish Bacground, Oxford University Press, 1964.

3 E. Wiegant Niepokoje literatury. Studia o prozie polskiej XX wieku, Wydawnictwo Wojewódzkiej Biblioteki Publicznej i Centrum Animacji Kultury, Poznań 2010, s. 188. 
Badaczka przywołuje pracę Jana Józefa Lipskiego o Kasprowiczu z 1967 roku, gdzie mowa jest o indywidualizmie jako podstawie kultury Zachodu, a w dalszej części szkicu pokazuje, że Tymon Terlecki, czerpiąc po równi z anglosaskiej tradycji modernizmu i z personalizmu katolickiego, biografizm traktował inaczej. Biografia jest bowiem w anglojęzycznym świecie pełnoprawnym elementem tradycji, która nigdy nie została podważona; wskazuje się na starożytne źródła gatunku (Plutarch Żywoty równoległe), na średniowieczne żywoty świętych, opowiadana w ten sposób „the British biographical tradition" wygląda na jednolite pasmo. Jak stwierdza Stella Tillyard, ,jej początki są opisane, jej charakter jest co najmniej w części przypisany do początków, a jej osiągnięcia są zwykle wyjaśniane na podstawie relacji do jej charakteru"4. Różnicę między kontynentalnym sposobem traktowania biografizmu a tradycją brytyjską można wyjaśniać różnie, ale analiza XX-wiecznych humanistycznych teorii mogłaby okazać się zbyt wąska. Badaczka, podpierając się anegdotyczną obserwacją dotyczącą Włoch, sprowadza rzecz do różnicy religijnej: w protestanckiej kulturze osoba, tak samo mężczyzna, jak i kobieta, powinna udowodnić swoją odpowiedzialność i wartość dla wspólnoty, wykazując swój prywatny wkład w jej rozwój; opowieść jest elementem samoświadomości, ujawnia i podkreśla walory moralne i dobrze przeżyte życie 5 . Tymczasem w katolickim otoczeniu opowiadanie o sobie jest traktowane jako co najmniej wstydliwe, jeśli nie - jako dowód wybujałego indywidualizmu, a wreszcie grzechu jakim jest pycha, prywatność zaś to sprawa między penitentem a spowiednikiem, który „odpuszcza” poszczególne partie, zarazem je unieważniając.

W jednolitym ciągu biograficznej tradycji wyróżniają się wybitne epizody.

\section{Lytton Strachey}

Omówienie brytyjskiej tradycji biografizmu nie może pominąć dokonań Samuela Johnsona (1709-1784), redaktora wpływowych pism, jak „The Gemtelmen's Magazine" $i$ „The Rambler”, poety, a przede wszystkim autora The Lifes of the English Poets, a także słownika języka angielskiego z 1755 roku. Johnson, zajmując się poetami angielskimi, sięgał do ich życia, sam

4 S. Tillard Biography and Modernity: Some Thoughs on Modernist Orgins, w: Writting Lives, Biography and Textuality, Identity and Representation in Early Modern England, ed. by K. Sharrp, S.N. Zwicker, Oxford University Press, 2008, s. 31.

5 Tamże. 
także stał się bohaterem takiego ujęcia; dzieło Jamesa Boswella The Life of Samuel Johnson (1791) określa się jako "the most celabrated biography in the English language"6. Znaczenie tej książki łączy się z regułami nowoczesnego społeczeństwa, w którym obowiązują zasady zysku, kariery i pracy. Cytowana już badaczka stwierdza: „Nie jest niespodzianką, że Życie Johnsona Boswella, jako historia prowincjusza, który przybył do Londynu i wybił się w nowoczesnej metropolii, natychmiast zostało obwołane arcydziełem"7. Kariera nowoczesnej biografii jako gatunku wiąże się bowiem ściśle z logiką kapitalizmu, z komercyjnym wymiarem tego typu książki, który zapewnia jej wiarygodność i pozwala dziełu na utrzymanie się na rynku; w najgłębszym wymiarze - biografizm jest wytworem logiki modernizmu zarówno w wymiarze ekonomicznym, jak i w sferze wartości. Byłoby pewnie nadinterpretacją wiązanie polskiego antybiografizmu z PRL-em, ale pozostaje faktem, że triumfalny powrót gatunku, jaki obecnie obserwujemy, nastąpił po transformacji ustrojowej.

O ile twórczość Johnsona nie odbiła się głębszym echem ani w polskim oświeceniu, ani w późniejszej polskiej literaturze, to w dwudziestoleciu międzywojennym sporym zainteresowaniem cieszył się kolejny autor wielkiego dokonania - Lytton Strachey (1880-1932). Strachey urodził się w Londynie jako 11 dziecko wysokiego urzędnika. Był członkiem kółka towarzyskiego wokół sióstr Stephen. Toby, przedwcześnie zmarły brat Virginii Woolf, studiował w Cambridge, jego kolegami byli Leonard Woolf i właśnie Lytton Strachey. Biograf Virginii Woolf tak o nim pisał:

To, że Lytton Strachey pewnego dnia zdobędzie nazwisko, wydawało się równie oczywiste. O ile ci młodzi ludzie mieli przywódcę, o tyle on nim był.Tak jak Saxon Sydney - Turner, był człowiekiem milczącym, ale jego milczenie było o wiele bardziej niepokojącej natury; bowiem podczas gdy Saxon Sydney - Turner mógł, wynurzywszy się, przynieść perłę mądrości, Strachey czasem pokazywał groźną płetwę, a czasem rząd złośliwych zębów. Jednym zjadliwym, oszczędnym zdaniem potrafił doprowadzić

6 Por. biografia Johnsona: The Oxford Companion to English Literature ed. by. M. Drabble, Oxford University Press, 1995. Co dość oczywiste, nie korzysta się dziś z pracy Boswella; krąg Johnsona stał się obiektem kolejnych intensywnych poszukiwań biograficznych w XX wieku. Por. Ch. Hibbert Samuel Johnson, A Personal Story, Palgrave Macmillan, 2009, po polsku J.L. Clifford Od kamyków do mozaiki. Zagadnienia biografii literackiej, przeł. A. Mysłowska, Czytelnik, Warszawa 1978, książka dotyczy poszukiwań wokół pani Thrale, protektorki Johnsona.

7 S.Tillard Biography and Modernity..., s. 34, przeł. A.N. 
zebranych do bezsilnego śmiechu, albo głupca do zapluwania się z wściekłości - a głupcem mógł być każdy.

Strachey początkowo onieśmielał Virginię, ale stał się jednym z jej najbliższych przyjaciół.W dzienniku pisarki pojawiają się liczne momenty związane ze Stracheyem.

Na przykład w 1918 roku, w poniedziałek, 21 stycznia, notowała:

Na herbacie był Lytton, został na obiedzie, a o dziesiątej wieczór oboje mieliśmy to uczucie spierzchnięcia warg i wyczerpania sił życiowych, które przychodzi po długich godzinach rozmowy. Lytton był swobodny i przemiły. Poza wszystkim innym zdał nam zadziwiającą relację z posiedzenia Brytyjskiego Towarzystwa Płci, które ma zebrania w Hampstead. Są niewiarygodnie szczerzy; pięćdziesiąt osób obojga płci i w różnym wieku dyskutowało otwarcie i bez skrępowania na takie tematy jak deformacje penisa u dziekana Swifta, używanie wc przez koty, samogwałt, kazirodztwo - kazirodztwo pomiędzy dzieckiem a rodzicem, jeśli obie strony są tego nieświadome, było głównym tematem, wywiedzionym z Freuda. Myślę o zapisaniu się. Lytton w pewnych momentach wykrzykiwał: „Penis!”. To był jego wkład w otwartość dyskusji. Rozmawialiśmy także o przyszłości świata - jak to chcielibyśmy, żeby nie istniały profesje; także o Keatsie, o starości, o polityce, hipnotyzmie Bloomsberry - o bardzo wielu rzeczach. ${ }^{9}$

Oboje byli jeszcze młodzi, nie do końca ukształtowani, chłonęli zachłannie psychoanalizę, zastanawiali się nad odrzuceniem ograniczeń, emancypacją, wyzwoleniem płci. 5 kwietnia 1918 roku Virginia Woolf zanotowała: „Lytton po koniuszku ogona rozpoznaje jak wygląda cała myśl, którą się ma w gło-

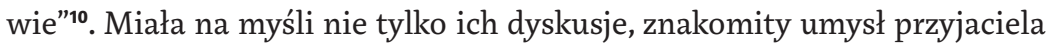
rozpoznawał jasno problemy, które dla innych ukrywały się w gąszczu faktów, opinii i myślowych stereotypów.

Z powodu słabego zdrowia Strachey nie został powołany do armii podczas I wojny światowej, było to niezwykle szczęśliwe rozwiązanie, zwłaszcza że

8 Q. Bell Virginia Woolf. Biografia, przeł. M. Lavergne, Twój Styl, Warszawa 2004, s. 148.

9 V. Woolf Chwile wolności, Dziennik 1915-1941, opr. A. Olivier Bell, wstęp Q. Bell, przeł. M. Heydel, Wydawnictwo Literackie, Kraków 2007, s. 55.

10 Tamże, s. 62. 
całe środowisko nastawione było pacyfistycznie. W 1918 roku ukazało się jego przełomowe dzieło o ludziach epoki królowej Wiktorii. Był to ogromny sukces, choć przyjaciele Stracheya oczekiwali czegoś jeszcze większego, na miarę jego geniuszu. Jak stwierdza Quentin Bell:

Eminent Victorians wyszła w maju. Przyjaciele Lyttona byli na rozmaite sposoby rozczarowani. Książka była oczywiście świetna - zawsze uważano za pewnik, że Lytton osiągnie świetność. Ale czy była w pełni go warta? Vanessa i Virginia były zdania, że nie. ${ }^{11}$

Nasuwa się tu pytanie, czy biografia w ogóle może być genialna, skoro świeci światłem odbitym, bazuje na interesującym potencjale swojego bohatera; czyż nawet świetna biografa nie jest mimo wszystko w pewien sposób wtórna? Pozostawię je bez odpowiedzi. Dzieło Stracheya zawiera cztery portrety, których bohaterami byli Cardinal Manning, Florence Nightingale, T. Arnold i Generał Gordon; w polskim przekładzie Antoniego Pańskiego w 1938 roku ukazało się pół książki z portretami Florence Nightingale i Generała Gordona, ta pierwsza postać mogła interesować polskiego czytelnika jako pionierka pielęgniarstwa, ten drugi - pojawia się jako postać w powieści W pustyni i w puszczy Sienkiewicza. Wydawca zapowiadał rychłe wydanie drugiego tomu, co nie nastąpiło z oczywistych powodów historycznych.

Swoje tezy wyłożył Strachey w niewielkim, doskonale napisanym, polemicznym wstępie do Eminent Victorans. Twierdził:

Historia epoki wiktoriańskiej nie zostanie nigdy napisana: za dużo o niej wiemy. Ignorancja bowiem - to pierwszy i niezbędny rekwizyt historyka: ignorancja, która upraszcza i podkreśla, która dokonywa wyboru jednych rzeczy a pomija inne, osiągając w ten sposób spokojną perfekcję, nieosiągalną dla najwyższej nawet sztuki. ${ }^{12}$

- wobec ogromnego materiału obyczajowego, żywej pamięci, monstrualnej zawartości archiwów - badacz nie może posługiwać się -

metodą systematycznej, skrupulatnej narracji: jeśli jest człowiekiem rozumnym, zastosuje subtelniejszą strategię. Atakować będzie swój

11 Q. Bell Virginia Woolf..., s. 326.

12 Ludzie epoki Wiktorii, Florence Nightingale, GenerałGordon, przeł. A. Pański, Rój, Warszawa 1938, s. 5. 
temat w miejscach nieoczekiwanych; uderzy na skrzydła; oświetli nagłym i przejmującym światłem reflektora ciemne, niezbadane dotąd zakamarki. $^{13}$

Strachey dyskutował z wysoką oceną epoki wiktoriańskiej, zamierzał przeciwstawić jej cztery portrety, znacznie komplikujące obraz, wydobywające hipokryzję, fałszywe wyobrażenie o hierarchii, bezduszną kolonialną biurokrację. Przestrzegał, że „istoty ludzkie są czymś zbyt ważnym, aby je można było traktować wyłącznie jako symptomaty epoki"; nie atakował więc wiktorianizmu wprost, frontalnie i ideologicznie, przeciwstawiał stereotypowi argumenty zaczerpnięte z życia wybitnych przedstawicieli epoki.

Część uwag Stracheya dotyczy podstaw gatunku biografii i postawy autora wobec opisywanej postaci:

Sztuka pisania życiorysu przeżywa, zdaje się, w Anglii złe czasy. Mieliśmy, to prawda, parę arcydzieł, ale nie mieliśmy nigdy - jak Francuzi - wielkiej tradycji biograficznej; nie mieliśmy Fontenellów ani Condorcetów i ich nieporównanych éloges, kondensujących na kilku wspaniałych stronicach ekstrakt egzystencji człowieka w jej różnorodnych odmianach. Najbardziej delikatna i najbardziej ludzka ze wszystkich gałęzi sztuki pisarskiej została u nas zdegradowana do rangi rzemiosła, którym zajmują się wyrobnicy literatury; nie przychodzi nam wcale na myśl, że napisać dobry życiorys jest może tak samo trudno, jak przeżyć dobre życie. Oto dwa grube tomy, którymi mamy zwyczaj oddawać hołd pamięci zmarłych - któż ich nie zna, z ich nieprzetrawioną masą materiału, byle jakim stylem, z ich nutą ckliwie panegiryczną i żałosnym brakiem wyboru, obiektywizmu, konstrukcji! Zżyliśmy się z nimi jak zżyliśmy się z widokiem konduktu pogrzebowego; są tak samo jak ów kondukt uroczystym obrządkiem żałobnym barbarzyńców. ${ }^{14}$

Biografie - zdaniem Stracheya - nie powinny polegać na możliwie dokładnym opisaniu życia: „pierwszym obowiązkiem biografa jest należyta zwięzłość - zwięzłość, która nakazuje opuszczać wszystko, co zbyteczne i nie pomijać niczego, co istotne”; drugim „utrzymywanie przez biografa własnej, niezależnej postawy duchowej”, bowiem: „nie jest jego zadaniem prawienie

L. Strachey Eminent Victorians, Chatto \& Windus, London 1918, s. 5-6.

14 Tamże, s. 7-8. 
komplementów". Biografia - to ani nie apologia, ani nie pamflet. Kończy, cytując słowa pewnego (przytoczonego anonimowo) mistrza: „Jen'impose rien; je ne propose rien; j'expose". Nie tylko w sprawie biografii i autobiografii rozgrywa się od dawna angielsko-francuska gra ambicji, połączona z typowym, dobrze znanym w Polsce toposem: oni mają lepiej... (lub gorzej), ich osiągnięcia są godne naśladowania, natomiast my pozostajemy w cieniu...

Każda z tez Stracheya wymagałaby rozwinięcia. Co jest zbyteczne? Na czym polega „właściwa postawa duchowa”? Z pewnością - konieczny jest dystans, biografowi nie wolno utożsamić się z postacią, musi też mieć jasną wizję rangi i dokonań człowieka, o którym pisze. Jedną z wyrazistych cech stylu Stracheya jest ironia, pokazywanie niejednoznacznych cech charakteru. Na przykład o Florence, którą w młodości usiłowano wtłoczyć w normalny scenariusz życiowy panny z wyższych sfer (czyli debiut towarzyszki - zaręczyny - małżeństwo), napisał :

Matka nie dała jeszcze całkiem za wygraną: Florence może przecież spędzać przynajmniej lato na wsi. Chwilami jednak, w obecności osób zaufanych, pani Nightingale prawie płakała. „Jesteśmy wszyscy jak kaczki - mówiła ze łzami w oczach - które wyhodowały wśród siebie dzikiego łabędzia". Ale biedna dama myliła się; ptak którego wyhodowała nie był łabędziem - był to orzeł. ${ }^{15}$

Florence Nightingale to według niego kobieta „opętana przez demona”, jej najbardziej wyrazistą cechą był aktywizm, nieustawanie w wysiłkach wiodących do realizacji jej idei, w ten sposób zamęczyła swojego sekretarza i Sydneya Herberta, polityka, który ją zawsze wspierał, a chodziło tylko o to, że nie dała im kilku dni wypoczynku, gdy ich stan zdrowia tego wymagał. Ona nie pochylała się nad jednostkami, dążyła do wielkich celów, chciała zmienić system.

Pionierka pielęgniarstwa podczas wojny krymskiej doprowadziła do tego, że szpital brytyjski w Skutari (na przedmieściach Konstantynopola) zaczął opiekować się rannymi (jej zasługi to organizacja pralni, kuchni, ogrzewania, rozmieszczenie w salach, wietrzenie, zaopatrzenie rannych w odzież i bieliznę, a także szczoteczki do mycia zębów, zorganizowanie możliwości wysyłki części żołdu do Anglii, co ograniczyło picie alkoholu, itd). Była nieustraszona w walce z biurokratyczną machiną: „Z dochodzeń, które potem zarządzono,

Tamże, s. 22. 
wynikało wyraźnie, że zło należało do najgorszych jakie istnieją - do takich mianowicie, które nie zostały spowodowane przez jakąś jedną określoną okoliczność i za które nikt nie ponosi wyraźniej odpowiedzialności"16. Nie zaprzestała walki o organizację wojskowej służby medycznej po powrocie do Anglii. Florence Nightingale w wizji Stracheya to nie słodki anioł, pochylający się nad łóżkiem rannego, obnażyła ona biurokratyczną, obojętną, bezmyślną machinę imperium. Z kolei generał Gordon, ceniony jako bohaterski dowódca, wcale do tego typu sławy nie dążył, kierowały nim idee religijne. Każdy z portretów w Eminent Victorians jest polemiczny wobec stereotypowych wyobrażeń na temat postaci.

Polemiczne wobec stereotypowych opinii były także dwa kolejne dzieła Stracheya: wydana w 1921 roku - biografia królowej Victorii i z roku 1928: Elisabeth and Essex: A tragic Story; ta druga biografia została uznana w Anglii za skandaliczną ze względu na ujęcie jako seksualnej (choć nie skonsumowanej) relacji królowej z pięknym, młodym arystokratą, którego wreszcie spotkał typowy los królewskich ukochanych - Elżbieta skazała go na śmierć.

Dwie późniejsze książki są dość obszerne, co dla dzieł biograficznych typowe - nietypowe dla biografii było eseistyczne podporządkowanie faktów pewnej założonej z góry tezie w Eminent Victorians i znaczna redukcja faktów. Biografia królowej Wiktorii uwypukla przemianę uroczej, niewinnej dziewczynki najpierw w królową, żonę ks. Alberta, a następnie usztywnioną wdowę, stojącą na straży obyczajów i pamięci męża, którego motywów działań politycznych nie rozumiała. Śledzimy jej rozwój od sympatycznego, ale trochę banalnego dziewczątka do imperialnej monarchini, a tezę podbudowują cytaty z banalnego dziennika, wypełnionego obserwacjami jak było „pięknie i przyjemnie”. Przemianom podlega także książę Albert: „Młodzieniec o słabej woli, który nie interesował się polityką i nigdy nie czytał gazet, wyrósł na człowieka niezłomnego charakteru, poświęcającego się stale i z całą energią najdonioślejszym zagadnieniom państwowym i bieżącym sprawom politycznym"17. Żadna z postaci nie została potraktowana pomnikowo, wszystkie są w ruchu, jaki nadaje im czas.

Ironia jest tropem zdecydowanie literackim, jej użycie w biografii, po pierwsze, dowodzi literackości, jej funkcje ideowe są liczne i ważne. Pokazuje ona niejednoznaczność pozycji piszącego, jest objawem jego dystansu wobec bohatera. Wydobywa niejednoznaczne cechy postaci, ujawnia momenty

16 Tamże, s. 26.

L. Strachey Królowa Wiktoria, przeł. J. Pański, Czytelnik, Warszawa 196o, s. 189. 
zetknięcia różnych punktów widzenia, ale nie prowadzi do rozstrzygnięcia racji, lecz uruchamia grę. Zamiast płaskiego, liniowego wywodu, daje efekt „przestrzenności”. Ironia relatywizuje, relatywność wiąże się zaś z poczuciem historyczności i zmienności. Nawet angielska konstytucja u Stracheya jest przedmiotem lekkiej kpiny:

Nieuchwytna istota, zwana konstytucją angielską, jest tworem żywym, rozwijającym się wraz z rozwojem stosunków między ludźmi i przybierającym coraz to nowe formy, zgodnie z subtelnymi i skomplikowanymi prawami, rządzącymi charakterem człowieka. Jest dzieckiem rozumu i przypadku. Ukształtował ją rozum ludzi z roku 1688; ale przypadek, że Jerzy I nie mówił po angielsku, nadał jej jedną z zasadniczych jej osobliwości - podporządkował gabinet ministrów premierowi i uniezależnił go od króla. Rozum lorda Greya uratował konstytucję od skostnienia i zagłady i skierował ją na drogę demokracji. A potem znów wmieszał się przypadek: młoda królowa poślubiła zdolnego i wytrwałego człowieka i oto wydawało się rzeczą prawdopodobną, że drzemiący od lat składnik konstytucji - nieodpowiedzialność władzy administracyjnej - stanie się jej rysem dominującym i zmieni całkowicie kierunek jej rozwoju. Ale możliwość, którą przypadek stworzył - przypadek też unicestwił. Książę małżonek umarł w sile wieku i konstytucja Anglii, odrzuciwszy z największą łatwością martwy człon swego ciała, żyła dalej swoim tajemniczym życiem, jak gdyby nic w ogóle nie zaszło. ${ }^{18}$

Ironia pojawia się też w Elżbieta $i$ Essex, okazją jest na przykład pojawienie się polskiego posła.W 1597 roku Paweł Działyński, poseł Zygmunta III, złożył na dworze angielskim protest w sprawie zatrzymania statków gdańskich wiozących towary do Hiszpanii, z którą Anglia była w stanie wojny.

Przybył z Polski ambasador, wspaniały magnat w długiej szacie z czarnego aksamitu, ozdobionej guzami z drogich kamieni, i został przyjęty przez Elżbietę na posłuchaniu. Monarchini rozsiadła się na tronie w otoczeniu dam dworu, członków Rady i dworzan i raczyła łaskawie nakłonić ucha ku kwiecistej mowie posła. Przemawiał po łacinie, podobno znakomicie; królowa słuchała i powoli opanowywało ją zdumienie. Ta mowa była zupełnie inna, niż się spodziewała. Zaledwie z rzadka komplement, 
a zamiast tego wyrzuty, wymówki, krytyka i - czyż to możliwe? - groźby. Upominano ją o zarozumiałość, gromiono za to, że zniszczyła polski handel, i zapowiadano wyraźnie, że król polski takiego postępowania nie zniesie. Zdumienie Elżbiety przeszło we wściekłość. Gdy poseł nareszcie zamilkł, królowa zerwała się na równe nogi: Expectavi orationem - wykrzyknęła - mihi vero querellam addixisti!!'

... i dalej długo krzyczała po łacinie. Wbrew pozorom usposobiło ją to bardzo dobrze, była z siebie dumna, gdyż dawno już nie używała publicznie łaciny, a jednak dała popis przed dworem. Paweł Działyński mógł więc liczyć na pewną łaskawość.

Życie Lyttona Stracheya także stało się przedmiotem biografiì ${ }^{\mathbf{2 0}}$ (bój się biografie, także twoje sprawy zostaną ujawnione!). Strachey mieszkał z małżeństwem, malarką Dorą Carrington i Ralphem Partridge. Po śmierci Lyttona Stracheya Dora usiłowała popełnić samobójstwo, postrzeliła się tuż po wizycie Woolfów i długo umierała, co wpłynęło na stan Virginii Woolf.

\section{Biographie romancée}

W tradycji francuskiej odróżnia się biographe factuellée (czyli dokumentacyjną) i biographie romancée. Ten drugi typ reprezentuje biografia, która wciąż opiera się na źródłach, ale napisana jest przy użyciu stylu i konstrukcji literackich, które upodabniają ją do powieści. Stanisław Cat Mackiewicz przełożył z francuskiego biographie romancée jako „biografia romansowana”; w felietonie z kwietnia 1933 roku twierdził: „Żyjemy pod znakiem biografii romansowanych, pedanterii, precyzji w odróżnianiu epok, stylów"21. W popularności biografistyki, i to tej mocno przetwarzającej materię dokumentarną, widział więc znak czasu. Interesowało go też, czy nowe prądy mają źródła angielskie czy francuskie? Podkreślał te angielskie, był bowiem w dwudziestoleciu zafascynowany Anglią, dopiero w trakcie II wojny, gdy los rzucił go na Wyspy Brytyjskie - całkowicie zmienił poglądy i napisał gniewne Londyniszcze.

L. Strachey Elżbieta i Essex. historia tragiczna, przeł. M. Godlewska, Czytelnik, Warszawa 1958, S. 136 .

Por. M. Holroyd Lytton Strachey: a critical biography, Heinemann, London 1968, i kolejne wydania. 
Twórczość André Maurois jest dowodem, że pomysły rodziły się na styku, w dialogu różnych impulsów. O ile wstęp Stracheya do Eminent Victorians można uznać za pewien rodzaj manifestu, składa się bowiem ze skrótowych deklaracji, Maurois jest autorem dużo bardziej systematycznej pracy Aspects de la biographie ${ }^{22}$, która powstała na podstawie seminarium autora w Trinity College w Cambridge w maju 1928 roku. André Maurois, francuski anglista, był autorem trzech biografii - Shelleya, Disraeliego i Byrona (w dwóch tomach).W jego przypadku mówić można o mieszance tradycji, książki Maurois interesowały zarówno publiczność francuską jak angielską, był świadomy obu tradycji i czerpał z obu.

W książce o aspektach biografii Maurois zadaje pytanie, czy istnieje nowoczesna biografia? Odpowiedź jest pozytywna, nowoczesna biografia to portret człowieka, daleki od apologii, wychodzący z założenia, że każde życie, także osób wielkich, składa się ze skomplikowanej prywatności:

W nowoczesnej biografii, jeśli jest uczciwa, zabrania się myśleć: „oto wielki król, wielki minister, wielki pisarz; wokół jego nazwiska narosła legenda; tę legendę i tylko ją, zamierzam pokazać”. Nie. Autor myśli: „Oto człowiek. Dysponuję pewną ilością dokumentów i świadectw, które go dotyczą. Zamierzam narysować prawdziwy portret. Jaki on będzie? Nie wiem. Nie chcę tego wiedzieć, zanim nie skończę. ${ }^{23}$

Aspekty, przez pryzmat których autor rozpatruje dzieło biograficzne, są następujące: biografia jako dzieło sztuki, jako wiedza, jako środek ekspresji, osobne rozdziały dotyczą relacji między biografią a powieścią oraz autobiografii.

Różnice między powieścią a biografią sprowadzają się do tego, że biograf nie operuje fikcją; w sprawie autobiografizmu autor przywołuje doktora Johnsona - najlepiej pisać autobiografię, bo czyje życie zna się lepiej? Gdy jednak uświadomimy sobie, jak trudno walczyć z pospolitym brakiem pamięci, wyższość autobiografii nad biografią okaże się pozorna.

Poza tym nowoczesną biografię cechować powinien pewien indyferentyzm:

Niektórzy powieściopisarze zabijają przyjemność estetyczną, zmuszają czytelnika, by podzielał stanowisko, jakie zajmują wobec problemów moralnych, które usiłują rozwiązać w swoich książkach. Ale najlepsi z nich

22 A. Maurois Aspects de la biographie, Grasset, Paris 1930.

23 Tamże, s. 27, przeł. A.N. 
wiedzą dobrze, że to nie jest zadanie artysty. Na przykład Czechow pisał do swego przyjaciela Suworina; „Proszę nie mieszać dwóch rzeczy: rozwiązania problemu i dobrego postawienia go. Tylko to drugie jest obowiązkiem artysty. W Annie Kareninie żaden problem nie zostaje rozwiązany, ale książka wywiera głębokie wrażenie, gdyż problemy zostały dobrze postawione. ${ }^{24}$

Biografia konfrontuje czytelnika z problemami otwartymi, nie podsuwa stanowiska i angażuje czytelnika w tym samym stopniu, co wybitne dzieło powieściowe, dowodzi tego przywołanie Anny Kareniny: „Piękno tragizmu jest jeszcze większe, gdy życie kończy się smutno ${ }^{25}$. W obcowaniu z biografią uruchamia się więc problematyka tragizmu, a dzięki jej przeżywaniu czytelnik ma możliwość doznać katharsis. Nowoczesna biografia byłaby więc konfrontacją z powszechnym, tragicznym wymiarem losu, a jej podobieństwo do powieści nie musi obejmować elementów formy. Jedynie „beletryzowana” wersja, bardzo popularna i dość sztuczna, posługuje się dialogami (które muszą być fikcyjne). Podobieństwo gatunków leży w sposobie emocjonalnego angażowana czytelnika w losy bohatera.

Praca nad biografią Byrona skonfrontowała autora z trudnym problemem kazirodztwa. Maurois nie uchylił się przed rozstrzygnięciem, choć nieco łagodził ostateczny wydźwięk:

Każdy biograf Byrona, czy chce tego czy nie, musi zająć jakieś stanowisko w sprawie „kazirodztwa”. Używam tego określenia zgodnie z tradycją, choć moim zdaniem kazirodztwo to było grzechem dość wyimaginowanym. Nie tylko dlatego, że Augusta Leigh była jedynie przyrodnią siostrą Byrona, ale i dlatego, że Byron nie widział jej prawie aż do chwili, gdy w roku 1813 ujrzał ją i pokochał. Jeśli chodzi o istnienie tej miłości, wyznaję, że nie rozumiem, jak można wątpić o niej po wydaniu Astarte, listów do Lady Malbourne i biografii Lady Byron. ${ }^{\mathbf{2 6}}$

Autor przytacza w sprawie romansu dowody ze źródeł, uznaje też za fakt, że Medora była córką z tego związku. Właśnie w tym punkcie w biografii Byrona

\footnotetext{
24 Tamże, s. 64, przeł. A.N.

25 Tamże, s. 67, przeł. A.N.

26 A. Maurois Byron, przeł. J. Pański, Rój, Warszawa 1937, s. 7.
} 
pojawia się węzeł tragiczny: „Sądzę, że traktując tę sprawę bez żadnej hipokryzji, udało mi się wzbudzić w czytelniku uczucia podziwu i litości, które - jak mi się zdaje - budzić musi charakter Byrona"27.

Maurois używa także ironii, pojawia się ona na przykład w opowieści o romansie włoskim Byrona z hrabiną Teresą Guiccioli:

Uważała się za kobietę wolną. Niepisane prawo małżeńskie było w tej prowincji zupełnie określone. Do szesnastego roku życia dziewczyna była zamknięta w klasztorze; potem szukano dla niej bogatego męża, a im był starszy, tym wyżej go ceniono. Młoda dziewczyna mogła widzieć swego narzeczonego killka razy w rozmównicy klasztornej. Czuła się dostatecznie szczęśliwa, że za cenę swego ciała zdobywała wolność. O miłości nie było mowy, ani z jednej, ani z drugiej strony. Hrabia Guiccioli miał sześćdziesiąt lat, kiedy poślubił Teresę; ona miała szesnaście. Od pierwszego dnia mieli oddzielne pokoje i Teresa nie przestała mówić doń „pan”. Był to dość miły staruszek (choć mówiono, że otruł pierwszą żonę i zamordował Manzoniego), kulturalny - był przyjacielem poety Alfieriego - intrygant i najbogatszy właściciel ziemski w Romanii. Ale starzec, nawet kulturalny, nie mógł zadowolić młodej kobiety. „Miłość - stwierdzał Byron - nie jest tym chłodnym, wyrachowanym uczuciem, jakim jest na Północy. To poważne zajęcie życiowe, to potrzeba, konieczność. Ktoś doskonale określił Włoszkę: istota, która kocha. One umieraja z miłości, szczególnie mieszkanki Romanii”. Przebyła już swój staż wierności; mąż, nabrawszy zaufania, stał się mniej czujny; czas był najwyższy na kochanka. ${ }^{28}$

Zwyczajowy okres wierności trwał rok, hrabina w momencie spotkania z poetą była już „wyzwolona” ze zwyczajowych więzów.

Biografię cechuje nieunikniony relatywizm moralny, pokazuje ona działanie norm obyczajowych w praktyce, nie w teorii, ujawnia - tam gdzie badacz jest w stanie sprawę udokumentować - wszelkie punkty, w których następuje przekroczenie, a ocena postaci zamykałaby drogę dla rozumienia dalszej opowieści; uważana byłaby także za błąd i nietakt ze strony biografa. Co prawda żywoty świętych uwzględniane są w genealogii gatunku, ale co do zasady nowoczesna biografia - to żywoty nieświętych, co wynika z samej koncepcji

27 Tamże.

28 Tamże, s. 292-293. 
nowoczesnej biografii. Konkretne fakty z życia Byrona i Shelleya postawiły biografa przed problemami, które w Aspects de la biographie są zaledwie zasygnalizowane, pokryte uspokajającym, porządkującym wykładem.

\section{W Polsce międzywojennej}

Przed wojną w Polsce zainteresowanie biografią było duże. Świadczą o tym przekłady Byrona Maurois i Eminent Victorians Stracheya. Zanim jednak zostały one opublikowane, Jerzy Stempowski, doskonale poinformowany o nowych trendach europejskich, w szkicu Biografia i literatura, zamieszczonym w 1932 roku na łamach „Wiadomości Literackich” pisał o „biografii powieściowej” (unikając niezgrabnego określenia „romansowana”). Jej popularność wskazywał jako jedno z najbardziej wyrazistych zjawisk „ostatnich pięciu lat” we Francji, przytaczał kolekcje wydawnictw francuskich, Plon i Gallimarda, podkreślał m.in. książkę Marii Czapskiej o Mickiewiczu. Zauważył popularność biografii także w Niemczech, dostrzegał inspiracje z Anglii, w tym rolę Stracheya. Biografia „urosła wkrótce na kontynencie do rozmiarów Lewiatana zasłaniającego sobą pół nieba literackiego Europy". Podobnie jak wielu późniejszych autorów akcentował (sprzeczny z marksizmem) indywidualizm ujęcia:

Rozwój biografii w naszych czasach jest, być może, jak sądzi Dymitr Filosofow („Za Swabodu” $1931 \mathrm{nr} 87$ i 88) reakcją przeciw patrzeniu na człowieka w kategoriach społecznych, jako na zjawisko masowe. ${ }^{29}$

Stempowski dostrzegał, że istnieją również oponenci tego gatunku, uznający, że: „biografia powieściowa jest rzeczą okropną, jest odrażającą mieszaniną pojęć i stylów". Na przykład Carlo Sforza uznawał biografię za "genre nauséabond" (co przełóżmy jako gatunek womitalny). Czyli - wyciągał z tego wniosek - krytycy stoją na stanowisku jednorodności, które wywodzi się z poetyk starożytnych, i tu nie odmówił sobie pięknej polemiki. Otóż - jak zauważył - Horacy „jako przykład złego smaku i pomieszania stylów poeta przytacza obraz pięknej kobiety zakończonej rybim ogonem". Tymczasem syrena „widnieje na każdym tramwaju warszawskim"30 i jakoś nie budzi

29 J. Stempowski Biografia i literatura, „Wiadomości Literackie” 1932 nr 11, przedruk w: tenże Chimera jako zwierzę pociągowe, oprac. J. Timoszewicz, Czytelnik, Warszawa 1988, s. 109-131, cytat ze s. 111.

Tamże, s. 112. 
kontrowersji estetycznych, choć jest chimerą. Mieszanie niejednorodnych elementów - to cecha współczesności.

Zastrzeżenia Stempowskiego budziło jednak „odbrązowianie”, czyli kampanie Boya. Szkic Boya o Mickiewiczu, jawnie polemiczny wobec apologii narodowego poety, porównać można ze strategią Stracheya w Eminent Victorians, nie jest to w ścisłym sensie biografia, to korekta stereotypowego obrazu, uzupełniająca go o elementy dyskusyjne. Zasługą Boya było wprowadzenie postaci Ksawery Deybel, wcześniej wstydliwie usuwanej na daleki plan. W pełni należy do gatunku biografii książka Boya Marysieńka Sobieska z 1937 roku, ujęcie to w dwudziestoleciu wywołało burzę jako pamflet na bohatera, zamach na pozycję w narodowym panteonie zwycięzcy spod Wiednia; do tej pory zjednej strony cieszy się niesłabnącym zainteresowaniem czytelników, z drugiej - bywa niezrozumiane jako przykład tego typu literatury, a nie praca historyczna.

Stanisław Cat Mackiewicz, doskonale czując gatunek, bronił Boya przed zarzutami:

Sobieski - to geniusz kawaleryjskiego manewru - czy czytając książkę Boya wiemy coś o manewrze kawaleryjskim, czy wiemy, jak pachnie pot konia lub jak pachną kwiaty na stepach! Natomiast mamy ciągle w nozdrzach zapach nocnego naczynia pod łóżkiem państwa Sobieskich. Oczywiście, że o buławach i proporcach Sobieskiego pisywało już wielu pisarzy o brandtowsko-matejkowskim kolorycie, to się publiczności znudziło, ujawnienie Sobieskiego jako erotomana ma swój pieprzyk, swoją oryginalność, swoją pomysłowość. Nie możemy i nie chcemy od Boya żądać, aby był historykiem. ${ }^{31}$

Według Cata charakterystyczna dla czasów nowoczesnych jest pozycja pośrednia między paszkwilem a panegirykiem. Mimo różnic poglądów politycznych Cat uważał Boya za znakomitego pisarza, największego w Polsce międzywojennej32.

Polska biografia w okresie międzywojennym miała się dobrze, gdyż była gatunkiem przeznaczonym dla szerokiej publiczności, z silną pozycją na rynku wydawniczym i europejskimi odniesieniami; jednocześnie wśród studiów

S. Mackiewicz Ksiq̨żka moich rozczarowań, s. 352-353.

32 Pisałam o tym w A. Nasiłowska Boy- Żeleński i Cat-Mackiewicz, „Wielogłos. Pismo Wydziału Polonistyki UJ" $2015 \mathrm{nr} 4$ (26). 
literackich przewagę - jako nowocześniejsza - zyskiwała postawa antybiograficzna. Julian Krzyżanowski pisał: „Najrozmaitsze względy sprawiły, że w okresie międzywojennym tradycyjna biografia literacka stała się przedmiotem energicznych ataków i w rezultacie znalazła się na indeksie prac naukowo-literackich" ${ }^{33}$; przypisywał tę zmianę przejściu „od studiów nad wybitnymi osobowościami do badań nad rolą masy jako twórczyni dziejów”34.

\section{Krzyżanowski: zwolennik biografii}

Julian Krzyżanowski - co wyjątkowe nawet wśród historyków literatury, bardziej pragmatycznie podchodzących do swoich studiów niż teoretycy i siłą rzeczy zmuszonych do akceptowania niejednorodności - był umiarkowanym zwolennikiem biografii. Co prawda sam jej nie uprawiał, ale znał i cenił dokonania angielskie i francuskie (powoływał się na Stracheya i Maurois), a także polskie, poza tym w swoich pracach syntetycznych uznawał zasadność wprowadzania podstawowej wiedzy o autorze w toku prezentacji.

Zagadnieniom biografii poświęcony jest w rozdział IX Historia literatury. Twórca w podręczniku Nauka o literaturze (1966). Pamiętam ze swoich studiów, że praca ta znalazła się w zestawie lektur, ale traktowana była jako czysta archaika, a jej tytuł (w skrócie NOL), ku uciesze studentów, wykładało się jako Niezidentyfikowane Obiekty Latające. Nie bez zdumienia niedawno odkryłam ponownie, że jednak jest to praca bardzo pożyteczna, pokazująca wstecz istnienie polskiej tradycji biografizmu.

Pamiętał Krzyżanowski o kpinach Słowackiego (w Beniowskim):

A but twój prawy zawieszą w Sybilli,

a o zaginiony lewy będą skargi...

a twa peruka, jeśli masz perukę

frenologistów poprze naukę

- a listy, , choćby to był tylko od ekonoma list albo przymierze wieczne miłości z Handzią lub Marylką," staną się obiektem niezdrowej ciekawości. Mimo ironii wobec zajętych „pośmiertną sławą" Krzyżanowski chwali jako pionierską biografię Słowackiego A. Małeckiego (1866) za zastosowanie metody portretu literackiego na wzór angielskiej formuły: Life and Letters.

J. Krzyżanowski Nauka o literaturze, Ossolineum, Wrocław 1966, s. 300.

34 Tamże, s. 300. 
Krzyżanowski uważał biografię za gatunek samodzielny i należący do literatury: „dobra biografia literacka jest sama dziełem sięgającym pogranicza sztuki i wskutek tego nie starzeje się w miarę narastania materiału dokumentarnego, autorowi jeszcze nie znanego" ${ }^{35}$. Powoływał się na to, że na przykład w Anglii nadal czyta się biografię Waltera Scotta napisaną przez J.G. Lockharta (1838), u nas nie, Małeckiego już się nie czyta, książka została zapomniana, choć wciąż funkcjonuje Żywot Adama Mickiewicza (189o) Władysława Mickiewicza - „znacznie słabszy literacko". Winę ponosi „pospolite u nas przekonanie, że nowy portret literacki musi być lepszy od starego i że potrafi go w zupełności zastąpić"36.

Przed autorem biografii stają wymagania wnikliwości psychologicznej, zbudowania portretu, precyzji psychologicznej i socjologicznej, odcyfrowania tajników osobowości. Przykładem niekonsekwencji są zadaniem Krzyżanowskiego prace Juliusza Kleinera, co prawda data urodzenia Słowackiego pojawia się tylko w przypisie, ale potem biografia bierze górę, co jeszcze bardziej widoczne jest w pracy o Mickiewiczu. Konia z rzędem temu, kto dokona dobrej, całościowej interpretacji III części Dziadów bez odwołania do procesu filomatów i okoliczności wileńsko- kowieńskiego okresu życia Mickiewicza.

Międzywojenną krytykę biografii Krzyżanowski łączy z marksizmem, skoro ujmuje, że była ona odrzucana ,jako przeżytek obcy «człowiekowi z ulicy»" ${ }^{37}$, przypisuje też odwrót od biografii wpływom rosyjskim, a więc formalizmowi. W coraz mniej sprzyjającej atmosferze zamiast książki opowieści („często niepotrzebnie” ${ }^{\text {38 }}$ ) pojawił się model „biografii w zalążku”"39 - pozbawionej narracji, w postaci przypisów do listów lub kroniki. Dopowiedzmy, że ten pierwszy rodzaj reprezentują na przykład przypisy Hanny Kirchner do Dzienników Zofii Nałkowskiej, choć autorka w końcu w ostatnich latach zdecydowała się na napisanie biografii ${ }^{40}$; ten drugi typ realizują prace

35

36

Tamże, s. 299.

Tamże.

Tamże, s. 300.

Tamże, s. 301.

Tamże.

Opracowania dzienników Zofii Nałkowskiej ukazywały się od lat 70. XX wieku, składają się na nie bardzo obszerne przypisy, które przedstawiają osoby, z którymi pisarka miała kontakt. Biografia Nałkowskiej to dzieło XXI wieku. Por. H. Kirchner Nałkowska albo Życie pisane, Grupa Wydawnicza Foksal, Warszawa 2015. 
Józefa Szczublewskiego, jak Żywot Osterwy ${ }^{41}$. Nawet w okresie, gdy zdecydowanie przeważała postawa antybiogaficzna, istniała potrzeba podejmowania wielu tematów ze względu na edycje, karierę dzienników pisarskich i inne elementy autobiograficzne w samej literaturze oraz potrzeby wyjaśniania tła różnych zjawisk.

Odrębnym zagadnieniem poruszonym przez autora jest status elementów biograficznych w syntetycznych zarysach historycznoliterackich:

Wcześniej jeszcze dokonał się exodus biografii z zarysów syntetycznych zwanych „historiami literatury” W książkach Lansona o literaturze francuskiej oraz Legouis-Casamiana o angielskiej podstawowe daty biograficzne pomieszczono, wraz z wiadomościami bibliograficznymi, w przypisach. U nas prace Tarnowskiego i Brücknera nie mają nawet takich informacyj. Zabieg francuski, możliwy w krajach bogatych nie tylko w encyklopedie, ale również słowniki biograficzne, ma swoją wymowę. ${ }^{42}$

Krzyżanowski zdecydował się postąpić wbrew przeważającym poglądom, powołując się na racje pragmatyczne:

Te względy natury czysto praktycznej sprawiły, że z mojej Historii literatury polskiej nie usunąłem wiadomości biograficznych, co więcej, położyłem pewien nacisk na tym wszystkim, co należy do zakresu biografii literackiej, co rzuca pewne światło na twórczość, co stanowi nieodzowny komentarz pozwalający głębiej wniknąć w istotę poddanych badaniu naukowemu zjawisk literackich.43

Przykładem kłopotów wynikających z wykluczenia biografii jest niemożność takiego skonstruowania syntezy historycznoliterackiej, by stanowiła ona wielostronne, łagodnie podane wprowadzenie, przyjazne również dla czytelnika nieprofesjonalnego; odcięcie się od biografii powoduje nieuchronne ciążenie historii literatury ku specjalizacji; tymczasem quantum wiedzy biograficznej jest niezbędne przy interpretacji utworów, a na wielkie zjawiska składają się zawsze indywidualne przypadki o pewnej powtarzalności.

41 J. Szczublewski Żywot Osterwy, PIW, Warszawa 1971. Józef Szczubleski był też autorem prac tego typu o Sienkiewiczu i Modrzejewskiej, mają one formę kronik.

42 J. Krzyżanowski Nauka o literaturze, s. 302.

43 Tamże. 
Obecny boom biograficzny w Polsce trwa już kilkanaście lat, podtrzymuje go niesłabnące zainteresowanie tego typu książkami na rynku księgarskim. Bardzo często stąpamy po śladach poprzedników, przeważnie - nieświadomie. Trzeba pewnej odwagi, by uprawiać biografistykę - twierdzi Nigel Hamilton, autor współczesnego, inteligentnego i żywo napisanego poradnika How to do Biography ${ }^{44}$. Coraz bardziej jest to przede wszystkim odwaga konfrontacji ze źródłami i faktami, zmaganie się z żywiołem literackiej opowieści, a nie - z nieprzychylnym biografistyce otoczeniem.

\section{Abstract}

\section{Anna Nasiłowska}

THE INSTITUTE OF LITERARY RESEARCH OF THE POLISH ACADEMY OF SCIENCES (WARSAW)

English, French and Polish Biographical Traditions: An Introduction

Nasiłowska outlines the development of European modernist biographical writing (Strachey, Maurois) and its reception in interwar Poland (Polish examples include Tadeusz Boy-Żeleński). This trend is juxtaposed with the scepticism with which biography was met after the structural turn, which had a profound impact on Polish literary studies. Having presented this historical backdrop, Nasiłowska discusses the work of literary historian Julian Krzyżanowski, an expert on European and Polish biography and a moderate supporter of the biographical method.

\section{Keywords}

biography, modernism, literary biography in Poland, biographical novel

44 N. Hamilton How to Do Biography. A Primer, Harvard University Press, 2012. 